\title{
当科に扮ける耳鳴外来の現状
}

\begin{tabular}{|c|c|c|}
\hline 長谷川淳一1) • 平田 & たら1)・立川 & 隆治1) ·田代 \\
\hline 谷光 徳晃 ${ }^{1)}$ • 小川 & 知幸1) - 石井 & 秀将1)・森 \\
\hline $\begin{array}{l}\text { 井門謙太郎 }{ }^{3)} \cdot \text { 工田 } \\
\text { 夜陣 } \quad \text { 紘治 }{ }^{1)}\end{array}$ & 昌矢 ${ }^{1)}$ ・福島 & 典之1) • 平川 \\
\hline
\end{tabular}

\section{Clinical Investigation of Tinnitus Therapy in Our Department}

\author{
Jun-Ichi Hasegawa, Shitau Hirata, Takaharu Tatsukawa, Toru Tashiro, \\ Noriaki Tanimitsu, Tomoyuki Ogawa, Hidemasa Ishii, Masaya Takumida, \\ Noriyuki Fukushima, Katsuhiro Hirakawa and Koji Yajin \\ (Hiroshima University School of Medicine) \\ Yoshiki Mori \\ (Kure Saiseikai Hospital) \\ Kentaro Imon \\ (Chugoku Rosai Hospital)
}

The clinical results of tinnitus therapy administered in our clinic were investigated. One hundred and ten patients with tinnitus (138 ears) were treated between 1994 and 1998. The characteristics of tinnitus were evaluated by the pitch match test, loudness balance test, intravenous lidocain test etc. All patients were treated by either intravenous lidocain injection, transtympanic injection of steroid, or electrical cochlear stimulation etc. or oral medication in general. The tinnitus was reduced in $56.5 \%$ of patients and disappeared in $12.3 \%$.

Key words : tinnitus, pitch match test, intravenous lidocain

はじめに

耳鳴は日常外来に执いてよく遭遇する疾患であり，村 井ら ${ }^{11}$ にると耳鼻科外来を受診した患者の約 $10 \%$ が耳 鳴を訴えたと報告している，耳鳴は患者にとってきわめ て不愉快な症状であるが，その病因や病態生理が解明さ れていないため，確立された決定的治療法がないのが現 状である.このような耳鳴患者に対して当科では耳鳴外 来で, 種々の検査, 治療を行ってきたが今回はその成績 ならびに治療法について検討したので報告する.

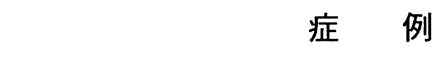

1. 対 象

1994年10月から1998年 7 月までの間に耳鳴を主訴とし て広島大学耳鼻咽喉科を受診し, 検査および治療を行っ た110名138耳を対象とした。

2. 耳鳴評価法

耳鳴のほとんどは患者自身の自覚的なものであるため, 耳鳴の性状をより客観的に評価するために，まず耳鳴の 音色, 大きさ, 持続, 苦痛度について詳細な問診を行っ たが，その際標準耳鳴検査法19842) に準じて問診を行っ 
た。

また初診時に通常の神経耳科学的検査と内耳道の $\mathrm{X}$ 線 検査を行った後, ピッチマッチテストとラウドネスバラ ンステストを耳鳴検査装置を用いて行った。またリド カイン静注は多施設で治療拈よび検査に使用され有効例 も多く報告されている3 ${ }^{3111}$ ため，耳鳴治療を希望する 患者に対して施行した.

3. 治 療

治療法は最初に薬物療法 (脳循環改善, 脳代謝賦活剤アデノシン三リン酸, ビンポセチン，ガンマオリザノー ル, 抗不安薬-エチゾラム, クロチアゼパム, フルジア ゼパム，ジアゼパム，ロフラセブ酸エチル，抗けいれん 剤一カルバマゼピン, 筋緊張治療薬-塩酸エペリゾン, 塩 酸チザニジン，ビタミン剤ーメコバラミン，等を主に併 用した)を行い，効果の見られない場合は症例によりキ シロカイン静注 ( $2 \%$ 静注用キシロカインを男性は 60 $\mathrm{mg}$ ，女性は $40 \mathrm{mg}$ を $20 \%$ ブドウ糖溶液 $20 \mathrm{ml}$ に混注し 3 分間で静注) ${ }^{111}$, 鼓室内ステロイド注入, 岬角電気刺 激法を適宜追加した．診断抢よび治療の概略を（図 1 ) と 示した.

\section{4. 改善度}

改善度の判定は, 治療開始後 1 力月以上加療を行った ものに対して評価を行った．自覚的評価で治療前の耳鳴

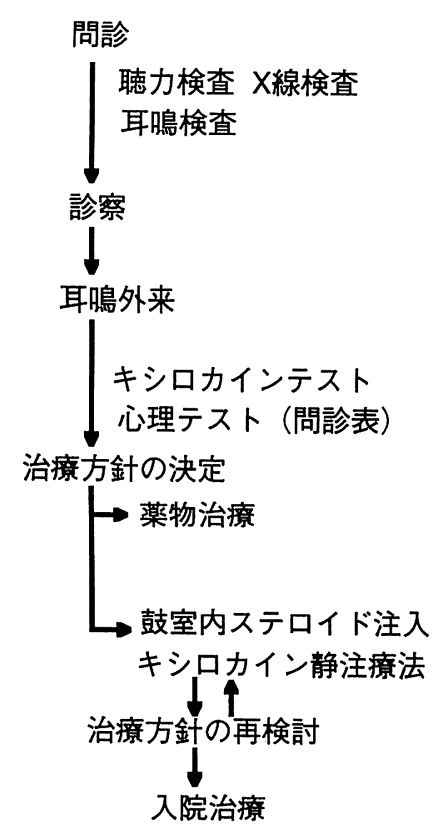

図 1 .耳鳴の診断扣よび治療の概略
の大きさを 10 として治療後 0 になったものを消失例， 1 〜 7有効例, $8 \sim 10$ を不変例, 11を増悪例と 4 段階に わけ評価した。な拈，今回の症例の統計解析には $\chi$ 二乗 検定を用いた。

\section{結 果}

1. 全症例の治療改善度

全症例138耳に拈ける改善度は消失 17 耳 $(12.3 \%)$, 改 善は61耳 $(44.2 \%)$, 不変は60耳 $(43.4 \%) て ゙$, 全症例の改 善度は $56.5 \%$ で増悪例はなかった（図 2)。

\section{2. 背景因子}

全症例中男性は65名 79 耳 $(57.2 \%)$ ，女性 45 名 59 耳 (42.8\%)でやや男性に多く見られた。また男性の改善度 は59.0\%(41/79 耳)，女性の改善率は $62.7 \%$ (37/59 耳) で(図 3 ), 有意差は認められないが，やや女性の改善率 が高かった。

患側別に改善度をみると(両側例はそれぞれとして数 学た)，右耳は $59.5 \%$ (42/71 耳)，左耳は $55.2 \%$ (36/66 耳), 頭鳴は $0 \%(0 / 1$ 耳) であった(図 4$)$.

また年齢別にみると 10 歳代が 4 耳，20歳代 4 耳，30歳 代13耳, 40歳代21耳, 50歳代35耳, 60 歳代41耳, 70 歳代18 耳，80歳代 2 耳と40〜60歳代に多く見られた．年齢と性 別の間には有意差は認められなかった.

年齢別改善度は，10歳代は $50 \%$ ( $2 / 4$ 耳)，20歳代は 50 $\%(2 / 4$ 耳)，30歳代は $30.8 \%$ (4/13耳)，40歳代は38.2 $\%$ (8/21 耳), 50 歳代は $74.3 \%$ (26/35 耳), 60 歳代は 68.3 $\%$ (27/41 耳), 70 歳代は $50 \%$ ( $9 / 18$ 耳), 80歳代は $0 \%$ (0/ 2 耳)であった（図 5 )。各年代ごとに検定を行ったが， 有意差は認められなかった。 しかし，30４0歳代の改善

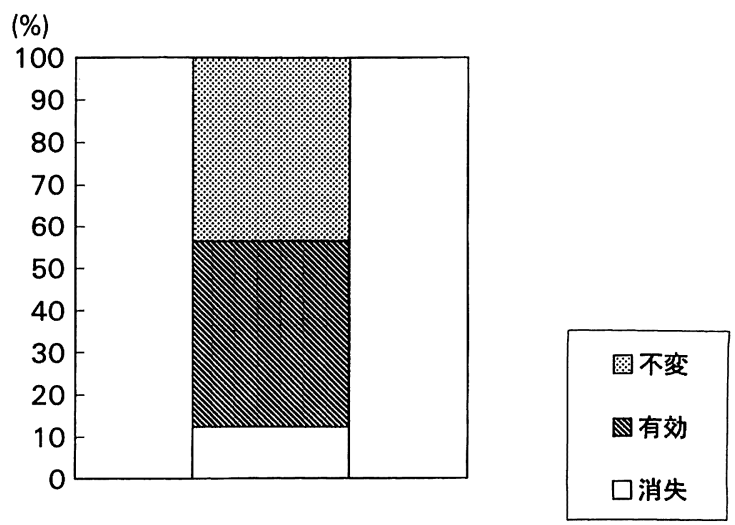

図 2 全症例の改善度 
(\%)

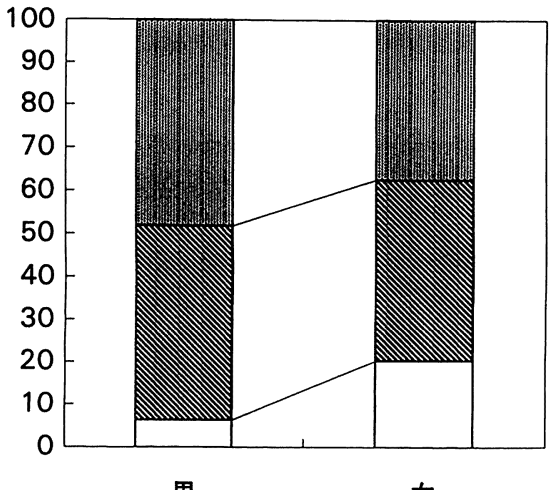

男

図 3 男女別改善度

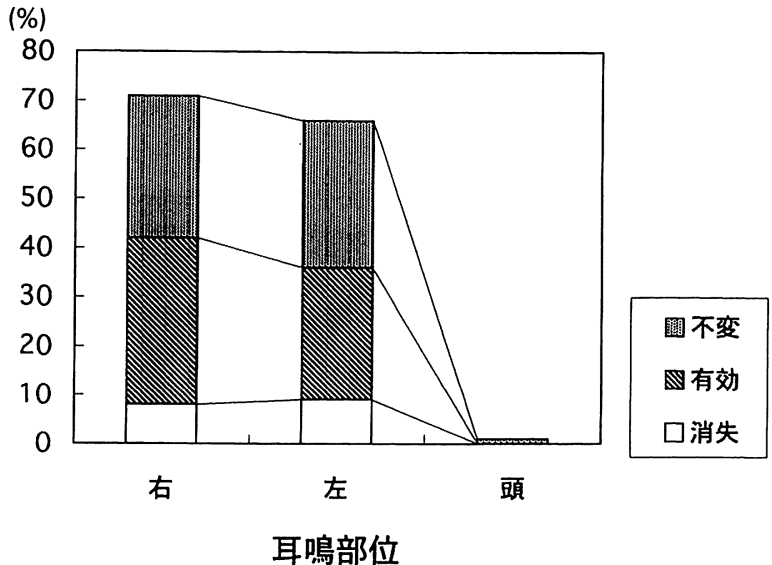

図 4 耳鳴部位と改善度

度が他の年代に比べ低い傾向が見られた。

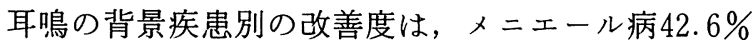
( $3 / 7$ 耳), 音響外傷 $0 \%(0 / 2$ 耳), 頭部外傷 $42.6 \%$ (3/7 耳), 原因不明の感音難聴 $64.3 \%$ (27/43 耳), 騒音性難 聴 $50 \%(5 / 10$ 耳), 老人性難聴 $42.6 \%(3 / 7$ 耳), 突発性難 聴64.7\%(11/17 耳), 中耳炎術後症63.6\%(7/11 耳), 平 衡機能障害 $90.9 \%$ (10/11 耳)，原因不明の耳鳴症 $34.8 \%$ (8/23 耳)であった(図 6$)$ ，メ二エール病, 突発性難聴, 音響外傷の症例では，急性期の治療後残存した耳鳴であ り, 中耳炎の既往がある例や中耳炎の手術後耳鳴治療を 希望した例を中耳炎例とした．原因不明の感音難聴とは 詳細な問診扣よび耳科学的検査あるいは全身的検索にも かかわらず，原因が全く見いだせない感音難聴のらち， 65歳未満の症例で, 老人性難聴は加齡の結果として生じ

る進行性の聴力障害いわゆる生理的变化と考兄られる症 例のらち65歳以上のもの3) とした. 原因不明の耳鳴症は 諸検査でも異常が認められず，耳鳴の自覚のあるものと した. 耳鳴の苦痛度が少なく一度しか受診していない者, 耳鳴があっても重症疾患 (脳神経疾患, 聴神経腫瘍等)の 除外をすることで安心し，継続して外来受診していない 症例は今回の検討では省いた。

罹病期間別改善度は 1 カ月以内は $80 \%(4 / 5$ 耳) , 1 〜 6 力月は $35.3 \%$ (6/17 耳), 7 カ月〜 1 年は $52 \%(13 / 25$ 耳), $1 \sim 5$ 年は $56.9 \%$ ( $41 / 72$ 耳), 5 年以上は 73.7 $\%(14 / 19$ 耳) で有意差はなかったが, 発症後 1 カ月以内 および 5 年以上の症例で高い改善度を示した (図 7 ).

治療歴の有無による改善度は治療歷のある例の改善度 が59.2\%(29/49 例)，ない例は55.1\%(49/89 例)でほぼ

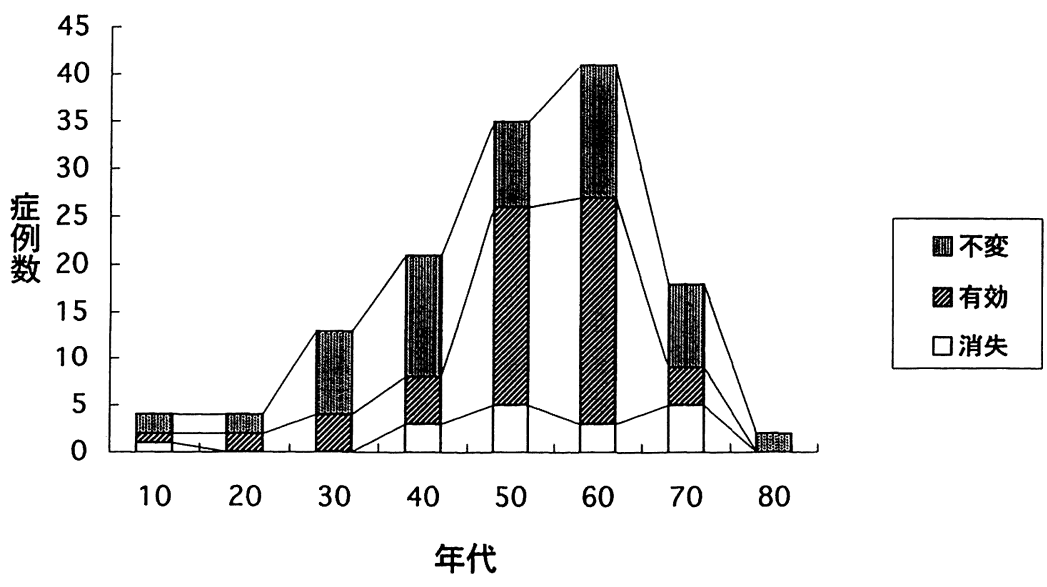

図 5 年代別改善度 


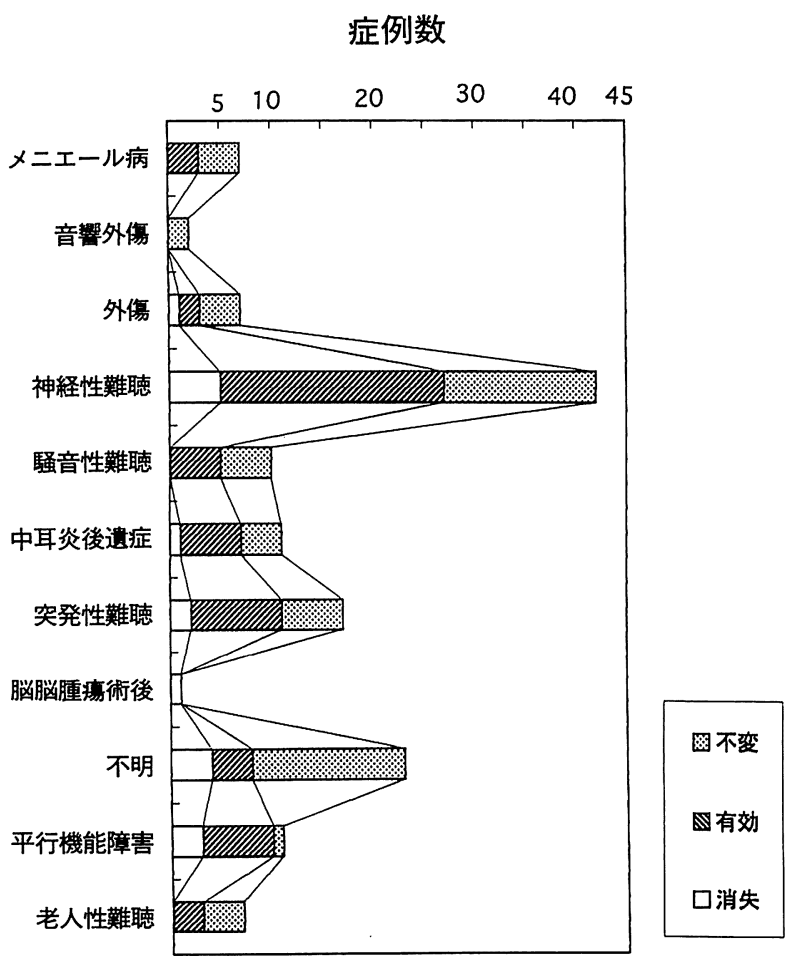

図 6 背景疾患之改善度

同程度であった(図 8 ).

患耳の平均聴力別改善度については, 聴力が $10 \mathrm{~dB}$ 以下は $22.2 \%$ (2/9 耳), $10 \sim 20 \mathrm{~dB}$ の者は $62.5 \%(20 / 32$ 耳), $20 \sim 30 \mathrm{~dB}$ は59. 0\% (23/39 耳), $30 \sim 40 \mathrm{~dB}$ は 36.8 $\%$ (7/19 耳), $40 \sim 50 \mathrm{~dB}$ は $57.1 \%$ ( $4 / 7$ 耳), $50 \sim 60 \mathrm{~dB}$ は60\%( $3 / 5$ 耳), $60 \sim 70 \mathrm{~dB}$ は $66.7 \%$ ( $4 / 6$ 耳), $70 \sim 80$

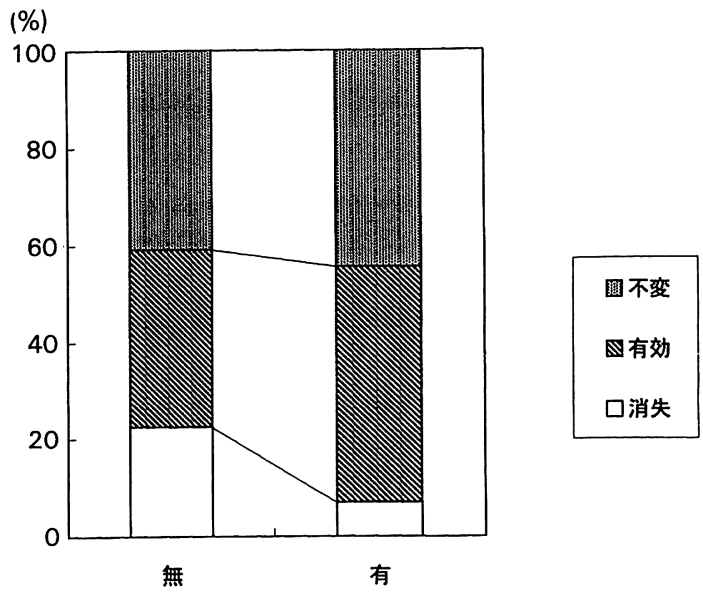

図 8 治療歴の有無による改善度

$\mathrm{dB}$ は $80 \%$ (4/5耳)，80〜90 dB は $66.7 \%(4 / 6$ 耳)，90〜 $110 \mathrm{~dB}$ は $100 \%(2 / 2$ 耳), $110 \mathrm{~dB}$ 以上は $100 \%(4 / 4$ 耳) であった。また $60 \mathrm{~dB}$ 以下の例と $60 \mathrm{~dB}$ 以上の例を分 けて比べると $60 \mathrm{~dB}$ 以下の例は $52.2 \%$ (59/113 耳), 60 $\mathrm{dB}$ 以上の例は $78.2 \%(18 / 23$ 耳) で, $60 \mathrm{~dB}$ 以上の例が $60 \mathrm{~dB}$ 以下の例より有意に改善度が高かった $(\mathrm{p}<0.05)$ (図 9 ).

3 . 耳鳴の性状

音色別の改善度は，清音成分の強い耳鳴，濁音成分の 強い耳鳴, 同程度に混じりあっているものと分けて検討 した．清音成分の強いものの改善度は57.9\%(44/76耳), 濁音成分の強いものは $62.1 \%(23 / 37$ 耳) で，同程度の例 は45.8\%(11/24 耳)で, 音色別の差は認められなかった.

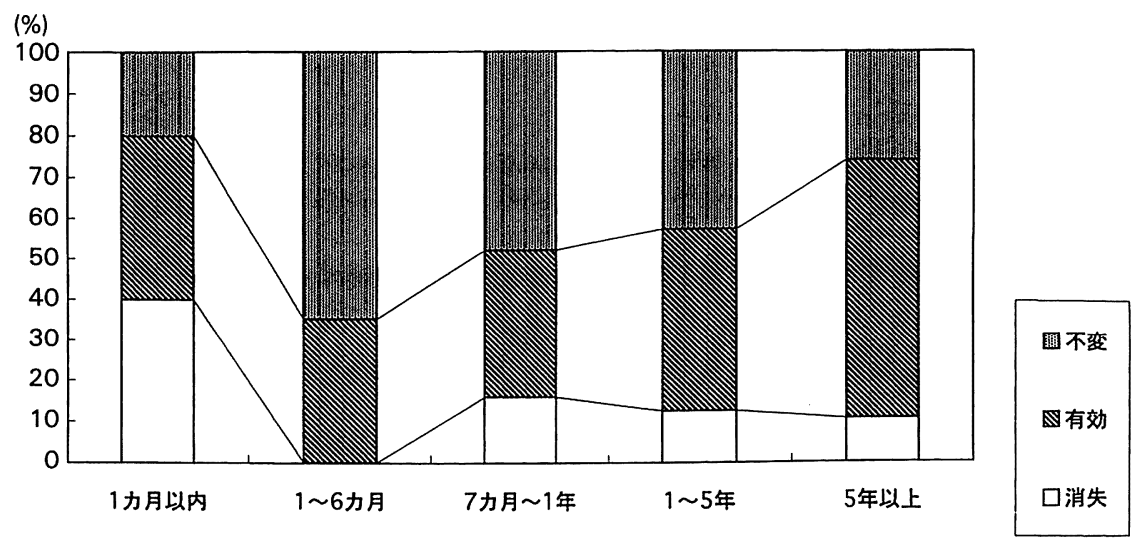

図 7 罹病期間別改善度 


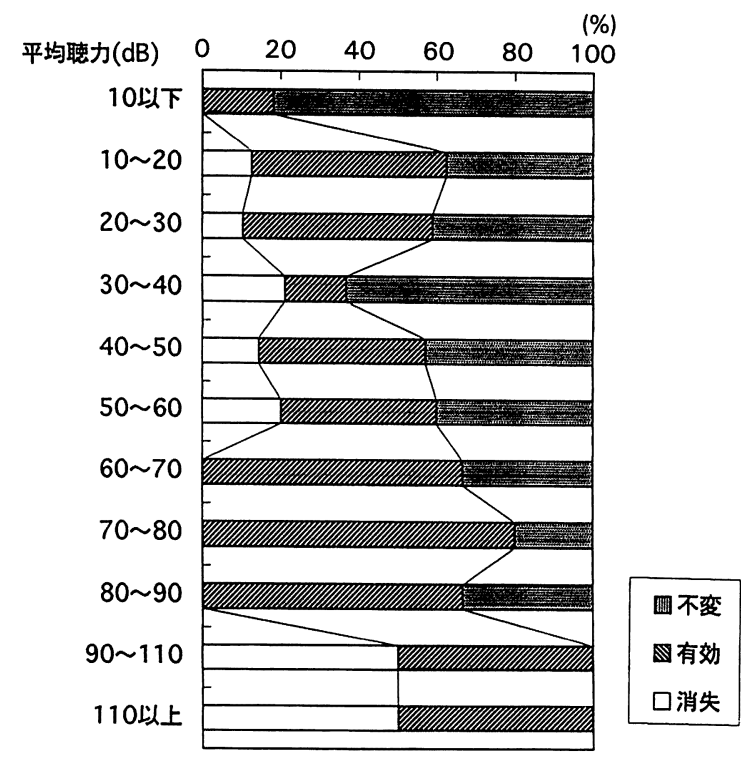

図 9 患耳平均聴力と改善度

ピッチマッチ検査による耳鳴周波数別改善度は，耳鳴 周波数が $1000 \mathrm{~Hz}$ 以下の例は63.0\%(29/46耳)，1000〜 $4000 \mathrm{~Hz}$ の例は $47.8 \%$ (11/23 耳), $4000 \mathrm{~Hz}$ 以上の例は $47.8 \%$ (22/46 耳) で, $4000 \mathrm{~Hz}$ 以下の例で総計すると 57.9\% (40/69 耳) で有意差は無かった。 ホワイトノイズ は17例あり, 改善率は70.6\%(12/17 耳)であった（図10).

\section{4.リドカイン静注検査}

リドカイン静注検査を施行した109例(リドカインに対 してショック既往のある者, 重篤な心疾患のある者, 皮
内反応陽性の者, 患者の拒否例を除いた)について各臨 床項目別に検討した

年齢別にリドカインによる改善度を検討すると10代は $25 \%$ (1/4 耳), 20代100\%(4/4 耳), 30代18.2\%(2/11耳), 40 代 $81.3 \%$ (13/16耳)，50代80\%(24/30耳)，60代 90.3 $\%(28 / 31$ 耳)，70代100\%(13/13耳)で，65歳未満と以上 で分けると前者は $67.7 \%(44 / 65$ 耳) で，後者は 97.2 $\%(41 / 44$ 耳) で有意差が認められた $(\mathrm{p}<0.01)$ (図11).

ピッチマッチ検査とリドカインによる耳鳴改善率は $1000 \mathrm{~Hz}$ 末満は $83.9 \%$ (26/31 耳), $1000 \sim 4000 \mathrm{~Hz}$ は90 $\%(18 / 20$ 耳) で, $4000 \mathrm{~Hz}$ は70.7\%(29/41 耳)，ホワイ トノイズは70.6\%(12/17 耳)で各群間に有意差は認めら れなかった(図12).

またリドカインによる耳鳴改善度と全般の耳鳴改善度 はリドカイン有効例の全般改善度は $61.2 \%(52 / 85$ 耳), 不変例は $61.1 \%(11 / 18$ 耳), 増悪例は $16.6 \%(1 / 6$ 耳) で 各項目とも有意差はなかった(図13).

5 . 治療法別改善度

治療法別の改善度は，内服のみで54.2\%(45/83 耳), カウンセリングと内服では57.6\%(19/33耳), カウンセ リングのみは $0 \%(0 / 1$ 耳 $)$, マスカーと内服では 100 $\%(2 / 2$ 耳), 鼓室内ステロイド注入を行った例では55.6 $\%(5 / 9$ 耳), リドカイン静脈注射では $50 \%$ (3/6耳), 放 置例は $100 \%$ (3/3 例)で，有意差はないものの全て $50 \%$ を超えた（図14）。

6. 使用薬剤別改善度

主に内服治療に用いた薬剤別に見ると, カルバマゼピ

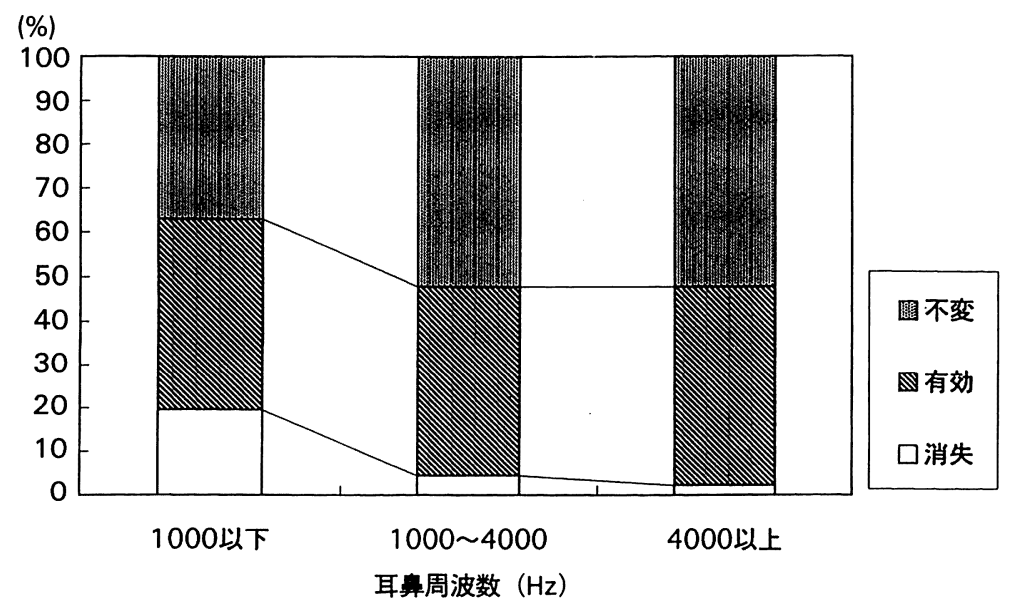

図10 耳鳴周波数と改善度 


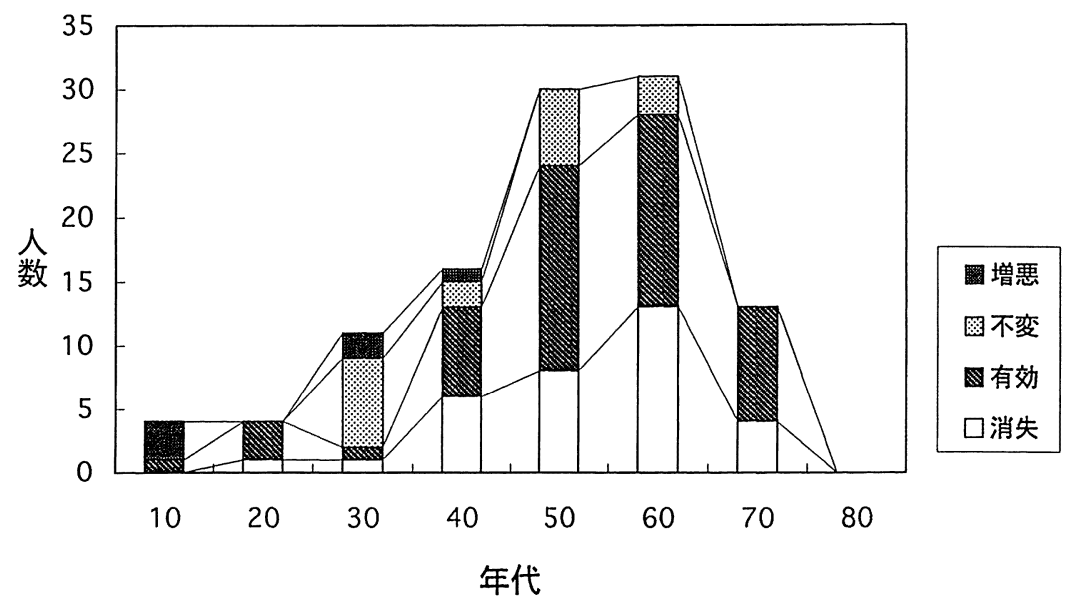

図11 リドカインの年代別改善率

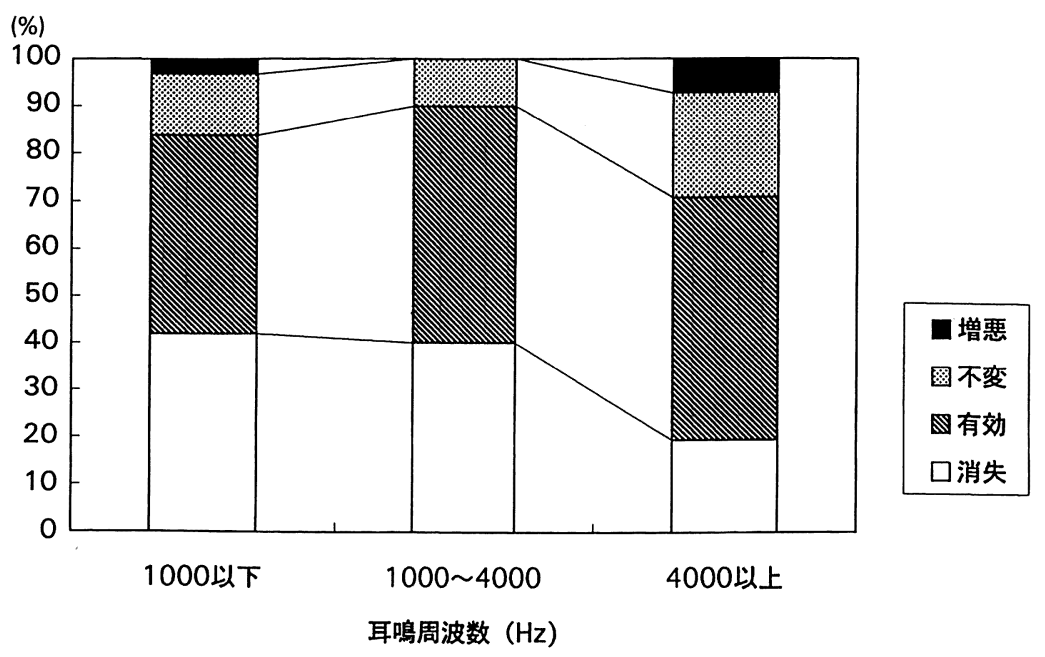

図12 耳鳴周波数とリドカイン有効率

ン(商品名テグレトール)は $58.5 \%(38 / 65$ 耳), フルジア ゼパム (商品名エリスパン)は $54.4 \%(37 / 68)$, 塩酸チザ ニジン(商品名テルネリン)は $63.8 \%(51 / 80)$, メコバラ ミン(商品名メチコバール)は $31.7 \%(13 / 41)$, アデノシ ン三リン酸(商品名アデホス)は $30.8 \%(12 / 39)$ ，クロチ アゼパム (商品名リーゼ)は $44.4 \%(8 / 18)$, エチゾラム (商 品名デパス)は $53.8 \%(7 / 13)$, ジアゼパム (商品名セルシ ン)は $62.5 \%(5 / 8$ 耳)であった。それぞれに有意差は認 めなかったが, 抗不安薬, カルバマゼピン, 筇緊張治療 剤に改善度が高い傾向が見られた(図15).

\section{考察}

当科での耳鳴治療の全般の改善率は63.8\%であり, 諸 家の報告 $(40 〜 80 \%)$ と同等の結果が得られた344778)10112)13). また，性別，患側別に見ると他の報告と同様に有意差は 見られなかった3(4)6)9).

年代別では30，40歳代の改善度が低く50，60歳代で高 い傾向が認められ，高齢者ほど改善度が高いとの諸家の 報告と同等の結果であった4)611114).

背景疾患別の治療効果について内耳性のものが改善度 が高いとする報告が多く見られる(13)4)6)91 12) が，当科の 症例では改善度は原因不明の耳鳴の改善度が低く, 平衡 


\section{全般の耳鳴改善度}

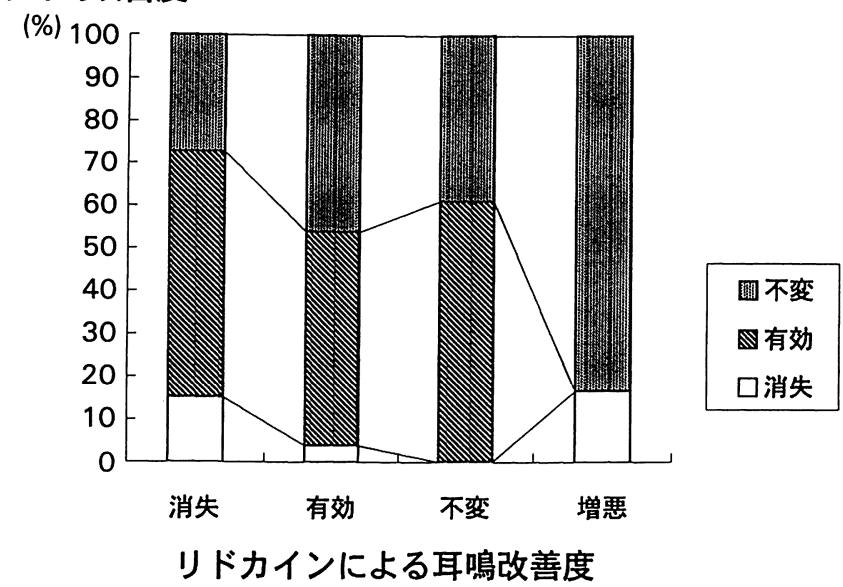

図13 リドカインによる耳鳴改善度と全般の耳鳴改善度

症例数

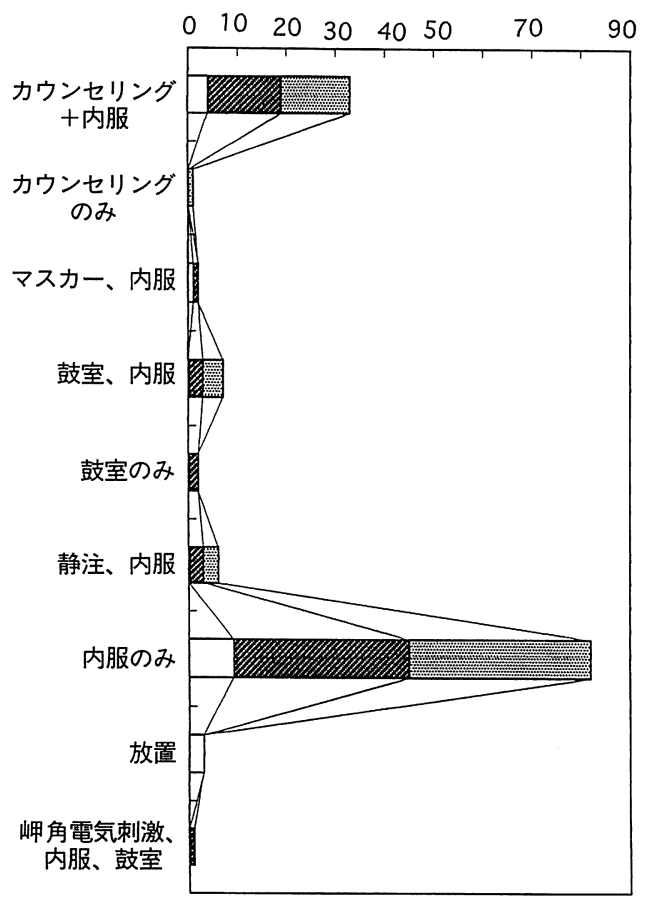

図14 治療法別改善度

機能障害の改善度が高かったものの, 検討した総数が少 ないためか疾患別に有意差は認められなかった。

罹病期間別改善度についても諸家の報告と同等に有意 差は認められなかった。

患耳の平均聴力に関しては聴力が悪い程耳鳴治療の有
改善度

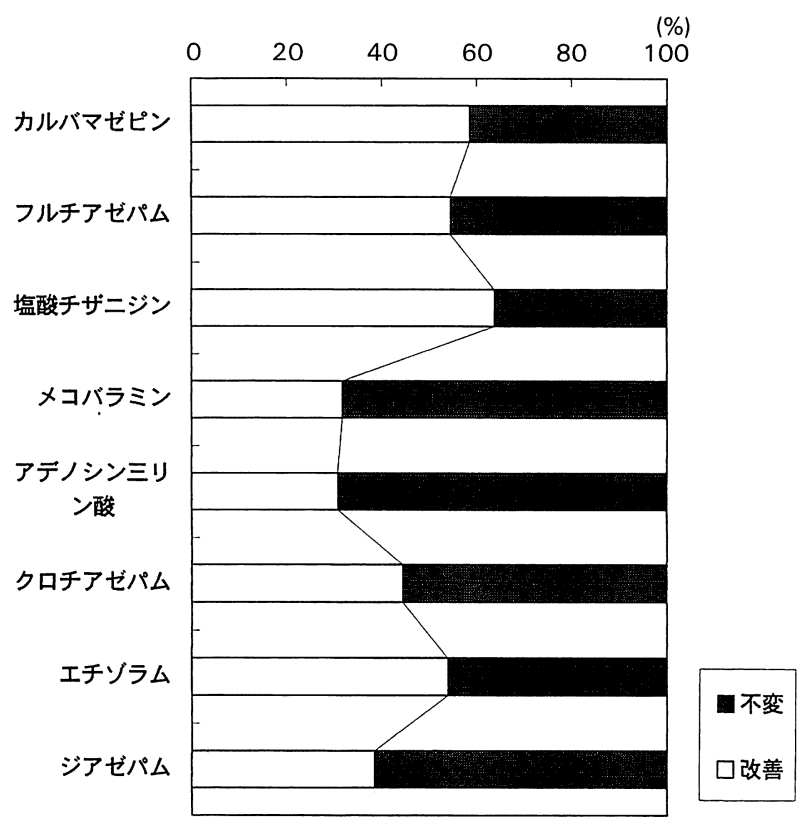

図15 薬剤と改善度

効率が高(7713) といわれて招り，当科の検討でも $60 \mathrm{~dB}$ 以下の難聴例と $60 \mathrm{~dB}$ 以上の難聴例での改善度を比較 すると高度難聴での改善度が有意に高かった。

耳鳴の性状別改善度は, 高音性耳鳴より低音性耳鳴の 方が改善度が高い713115), 高音性耳鳴の改善度が良い16), 雑音性耳鳴 (ホワイトノイズ例) は蝸牛の障害部位が広範 で治療抵抗性のことが多い17)など種々の報告があるが， 
当科ではピッチマッチ検査で $1000 \mathrm{~Hz}$ 以下とホワイト ノイズ例の改善度が高かった。この理由として，耳鳴ピ ッチと障害部位がほぼ一致するとの考えに基づくと，蝸 牛頂回転のみならず蝸牛全体あるいは内耳以外の部位 (後迷路性難聴)にも有効であることを推察させる．しか し総数が少ないこと, 内耳性, 後迷路性に分けて検討し ていないこと，ラウドネスバランステストの検討を行っ ていないことなどより今後症例を増やして検討する必要 がある．また音色別にみると，諸家の報告では清音成分 より濁音成分強いほど改善度は高(3)418110121) との報告が あるが，当科症例では改善率はほぼ同等であった．耳鳴 の性状が濁音性のものはピッチ上有意に $500 \mathrm{~Hz}$ 以下の 低音性耳鳴が多く，改善度が高いとの報告もあるが，ピ ッチ別の改善度も有意差はなく, 一定の傾向は認めなか ったので，今後は症例を重ねて検討していきたい。

リドカインは1935年に Barany) が耳鳴に対する有効 性を報告したのが最初であるが，それ以来耳鳴に対して 60 80\%が有効であるという多数の報告が見られる711113118). その作用機序に関しては, 蝸牛, 蝸牛神経の可能性を示 唆する報告もあれば中枢性の可能性を示唆する報告もみ られる。.小川ら ${ }^{18)}$ は内耳性耳鳴に対し有効であったと 報告し，鈴木ら $\left.{ }^{19}\right)$ はキシロカイン静注により臨床例で は 5 波の潜時の延長が認められ，後迷路性の耳鳴に有効 であると推察し, 坂田 ${ }^{9}$ は臨床上も蝸牛性耳鳴に対する リドカインの効果は少ないと報告している. 我々は, リ ドカインの静脈内投与をその作用機序にかかわらず，一 時的にでも耳鳴を軽減できるという心理的な効果を目的 として，耳鳴治療を希望する患者に検査を施行した，そ の結果, リドカイン静注検査による耳鳴改善度が65歳以 上で有意に高かった．これは高㱓になるほど，リドカイ ンに対する耐性が少ないため，有効率が高いと考兄られ るとの報告と一致した ${ }^{20)}$ ，その一方，リドカイン静注療 法による改善度は $50 \%$ とやや低かった。これは対象とな った症例が内服療法で効果がそしかった症例が多いこと， 患者側の意向で最大 5 回（ほとんどが $1 \sim 2$ 回）しか継続 して行っていないことによると思われる．山中ら よると $8 \sim 10$ 回(最大 56 回)行ってこと効果があるとの報 告むみられることを考它わせると，今後は回数を増や し再検討する必要があると思われた。

使用薬剤についてはまたカルバマゼピン, 塩酸チザニ ジン，抗不安薬の耳鳴に対する有効性が報告されて护 $\eta^{21122)}$ ，我々もこれらを主体として治療した．今回の
検討では, 塩酸チザニジン, カルバマゼピン, クロチア ゼハムの有効性が高かった，抗不安剂は精神神経学的な 要素の強い例に有効であると思われるが，他の薬剤につ いては，検查所見や背景因子との関連は見いだせなかっ た. 症例を重ね, リドカインの有効率との関連も今後検 討していくつもりである.

耳鳴の総合的治療を考学る上に打いては精神神経学的 要素も無視できない. House ${ }^{23)}$ は重度の耳鳴患者はその 41\%に神経症的傾向を，36\%にうつ傾向を認めたとして 招り Simpson ${ }^{24)}$ は耳鳴患者の約 3 分の 1 にうつ傾向が あったと報告している．さらにプラセボ効果でも $40 \%$ で 苦痛が軽減されたとの報告もある ${ }^{25)}$ ，今回例数は少ない ものの，仕事上や家庭内のストレス等が詳細な問診の過 程で明らかになり，カウンセリングのみで耳鳴の軽減し た症例もある．抗不安薬の改善度が高かったのは，精神 神経的要素の強い症例に対する有効性が高い可能性が示 唆された.

また耳鳴の治療の一環として精神心理学的療法を積極 的に取り入れていく必要性を痛感した。加えて降圧剤, 抗パーキンソン病剤, ジギタリス製剤, 抗不安剤は薬剤 性らつを起こすこともあり 25$)$ それが原因で耳鳴が発症 するともいわれており，他科での治療歴に留意するとと もに, 薬剤を投与する際には, 効果の得られない薬㓮を 漫然と投与することで，逆に増悪することのないように 注意する必要があると思われた。

耳鳴の治療はその原因が明らかでない現在の段階では 個々の症例を詳細に検討し，治療希望があれば，個人の 要求にあわせ，基本的には薬物治療を中心とし，さらに 症例に応じてリドカイン静注もしくは点滴療法, マス カー治療, 鼓室内ステロイド注入, 鼓室内リドカイン注 入，岬角電気刺激治療など組み合わせると共にカウンセ リングによる精神心理学的療法も併せて行らことが重要 ではないかと思われた。

$$
\text { まとめ }
$$

当科の耳鳴外来の現状について検討を行い報告した.

1. 1994年10月～1998年 7 月の耳鳴症例110名138耳に ついて検討した.

2. 全症例の改善度は $56.5 \%$ で，らち消失例は $12.3 \%$ であった。

3. 患耳の平均聴力が $60 \mathrm{~dB}$ 以上の例と $60 \mathrm{~dB}$ 以下 を比べると有意に $60 \mathrm{~dB}$ 以上の高度難聴群の改善度が 
高かった.

4. 65歳以上の例のリドカインによる耳鳴改善度は65 歳以下の例の改善度と比べ有意に高かった。

5 . 精神神経学的要素, 内科的要因も考慮し, 個々の 症例ごとに個人の要望にそった治療が必要と思われた。

\section{参考文献}

1 ）村井和夫, 曽田豊二, 朝隈慎一郎, 他 : 耳鳴, 第84回日本 耳鼻咽喉科学会総会研修会テキスト，6〜40,1993。

2）村井和夫：耳鳴の検査. 耳鼻咽喉科頭頸部外科 MOOK No. 22 耳鳴(野村恭也, 本庄 踇編).54 66頁, 金原出 版, 東京, 1992.

3）上田晋介：耳鳴の臨床的研究ーリドカイン静注療法によ る耳鳴治療一。日耳鼻 $95: 1389 \sim 1397,1992$.

4 ) 真鍋恭弘: 耳鳴の評価と治療 一福井医大耳鳴外来での試 久一. 耳鼻臨床 補63: 74 80, 1993.

5 ) Barany R : Die Beeinflussug des Ohrensauren durch intravenous injizierte lokal anesthetica. Acta Otolaryngol (Stockh) 23 : 201 203, 1935.

6) 安田宏一：耳鳴に対する局所麻醉剂静注の効果, 耳喉 45 : $97 \sim 100,1973$.

7）卜部信行, 杉原三郎, 山本哲夫, 他 : 塩酸りドカイン静注 投与による耳鳴抑制効果. 耳鼾臨床 $77: 1429 \sim 1436,1984$.

8）上田晋介, 麻生 伸, 吉田行夫, 他 : 塩酸リドカインによ る耳鳴治療. Audiology Japan $31 ：$ 117 122, 1988.

9）坂田英治：いわゆる『蝸牛性耳鳴』の治療 一粘莫麻酔剤 の中耳腔注入による内耳ブロック療法の試み一。目鼻 $79: 742 \sim 746,1976$.

10）小川 郁：耳鳴に対するリドカイン持続点滴療法の検討. Otol Jpn 4 : 304 309, 1994.

11）朝涱慎一郎, 中島恒彦, 平島健二郎, 他: キシロカイン静 注投与による耳鳴の治療.耳鼻 $30: 309 \sim 314,1982$.

12）杉原三郎，卜部信行, 山本哲夫, 他: 耳鳴に対するキシロ カイン静注投与の効果. 耳鼻 $30: 306 〜 309,1984$.

13）山中栄三, 暁 清文, 佐伯忠彦, 他 : キシロカイン静注に
よる耳鳴治療効果の検討. 日耳鼻 92 : 566〜 573, 1989.

14）小田 㡄：耳鳴治療の評価について. 耳鼻臨床 87 : 291〜 297, 1994.

15）井上秀明，本多芳男，清水淑郎，他：塩酸リドカイン静注 とパルス音刺激による耳鳴治療の臨床効果. 耳展 $27: 597$ $\sim 601,1984$.

16）斎藤武久, 斎藤 等, 黒川泰資, 他 : 耳鳴に対するバルプ 口酸ナトリウムの効果. 耳鼻臨床 $79: 851 \sim 857,1986$.

17）上田晋介：耳鳴の臨床的研究 一耳鳴のピッチ及びラウド

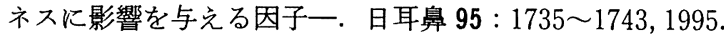

18）小川 郁, 神崎 龙, Jochen Schacht : 蝸牛感覚上皮のイ ノシトールリン酸代謝に対するリドカインの影響. Otol Jpn $4: 651 \sim 655,1994$.

19）鈴木 衞, 工田昌也, 夜陣紘治, 他：キシロカイン静注の $\mathrm{ABR}$ ，蝸電図に及ぼす变化一実験的ならびに臨床的観 察一. Audiology Japan $26: 636 \sim 646,1983$.

20）森川定雄 : 局所麻酔薬の吸収. 局所麻酔薬反応 一基礎と 臨床一. 23～50頁，診療新社，大阪，1991。

21) Melding PS, Goodey RJ and Thorne PR : The use of intravenous lidocainin the diagnosis and treatment of tinnitus. J Laryngol Otol 92 : 115 121, 1978.

22）北原正章，鈴木幸男：耳鳴の薬物治療. 耳鼻咽喉科頭頸部 外科 MOOK 22, 95 101頁，金原出版，東京， 1992.

23) House PR : Personality of the tinnitus patients. Tinnitus CIBA Foundation Symposium 85. pp 193 203, Pitman Medical, London, 1986.

24) Simpson RB : Phychiatric diagnosis in patients with psychologic dizziness or severe tinnitus. J Otolaryngol $17: 325 \sim 330,1988$.

25）小川 郁：高㱓者の聴覚障害 一耳鳴一. 耳喉頭頸 $70: 27$ $\sim 31,1998$.

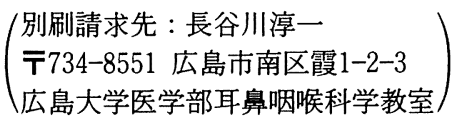

